\title{
Structure and density population of the invasive mollusc Limnoperna fortunei associated with Eichhornia crassipes in lakes of the Middle Paraná floodplain
}

\author{
Gabriela E. MUSIN,,$^{1 *}$ Florencia ROJAS MOLINA, ${ }^{1,2}$ Federico GIRI,,$^{1,3}$ Verónica WILLINER ${ }^{1,3}$ \\ ${ }^{1}$ Instituto Nacional de Limnología (CONICET - UNL), Ciudad Universitaria, 3000 Santa Fe; ${ }^{2}$ Escuela Superior de Sanidad “Dr. Ramón \\ Carrillo", Facultad de Bioquímica y Ciencias Biológicas, Universidad Nacional del Litoral, Ciudad Universitaria, 3000 Santa Fe; \\ ${ }^{3}$ Facultad de Humanidades y Ciencias, Universidad Nacional del Litoral, Ciudad Universitaria, 3000 Santa Fe, Argentina \\ *Corresponding author: gabriela_musin@hotmail.com
}

\begin{abstract}
The roots of Eichhornia crassipes provide different microhabitats for invertebrates, including substrate for the Asian invasive bivalve Limnoperna fortunei. This work evaluated the density and size structure of $\mathrm{L}$. fortunei on the roots of $\mathrm{E}$. crassipes in lentic water bodies associated with the Middle Paraná floodplain. The field work was carried out between November 2009-2010, covering different phases of the hydrological regime. Floating meadows of E. crassipes were sampled monthly in two lakes with different degrees of connection to the main channel of the Paraná River. Bivalve densities were not associated with variations of the biomass of $\mathrm{E}$. crassipes roots and the highest mussel densities were recorded during months of high temperature. The maximum size recorded in both lakes corresponded to individuals approximately 2.5 years old; however, up to $75 \%$ of the molluscs were represented by pre-reproductive individuals (up to 6 months old). In these lakes with soft bottom and limited hard substrates, E. crassipes is an important site for the mussel attachment during its early stages of development and could not be the final site of settlement during its lifecycle.
\end{abstract}

Key words: Golden mussel; invasions; aquatic macrophytes; substrate; hydrological regime; population dynamics.

Received: September 2014. Accepted: April 2015.

\section{INTRODUCTION}

Today, one of the main problems to resolve regarding the conservation of diversity in freshwater environments is that of biological invasions whose consequences vary according to the environmental conditions of the system (Sala et al., 2000). In Argentina, Limnoperna fortunei (Dunker 1857) or golden mussel is an aggressive invader due to its ecological effects on benthic, plankton and fish communities, as well as on water-column properties, and on man-made structures (Darrigran et al., 1998; Montalto et al., 1999; Sylvester et al., 2005; Boltovskoy et al., 2009; Rojas Molina et al., 2010; Darrigran, 2010; Boltovskoy and Correa, 2015). Since its introduction in South America in 1991, this mollusc has spread widely in the Río de la Plata Basin, also reaching several other minor watersheds (Mar Chiquita, Guaíba, Tramandaí, and Patos-Mirim (Oliveira et al., 2014). At present its distribution includes Argentina, Uruguay, Paraguay, Bolivia and Brazil (Boltovskoy et al., 2006; Oliveira et al., 2006; Darrigran et al., 2012).

The golden mussel, displays several traits that are thought to have been instrumental for its geographic expansion. Among these, of particular importance are early sexual maturation, high fertility, planktonic larvae, broad ranges of environmental tolerance, the epifaunal way of life, and the local absence of competing epifaunal, sessile organisms (Darrigran, 2002; Boltovskoy et al., 2006; Karatayev et al., 2007). Limnoperna fortunei attaches to a wide variety of substrates, both natural (trunks, rocks, aquatic plants and other organisms, and compacted siltsand), and artificial (such as piers, filters, tubes, and walls) (Darrigran, 2002; Karatayev et al., 2007; Rojas Molina and Williner, 2013).

Studies on the population dynamics of invasive mussels provide the necessary information to understand their ecology, invasion dynamics and the effects of these species on the invaded ecosystem. Also, this information is necessary for the design and implementation of monitoring and controlling strategies of invasive species (Darrigran et al., 2003; Boltovskoy et al., 2009; Simberloff et al., 2013). Despite the fact that mussel densities have been estimated numerous times in different areas and on different substrata, their usefulness as an indicator of the ecological importance of the bivalve is very limited. Indeed, practically all these figures refer to abundances over very restricted areas, usually less than $1 \mathrm{~m}^{2}$ in size, and the sites in question are not selected at random, either because they are densely covered by mussels, or are ad hoc deployed artificial substrata (Correa et al., 2015). Particularly, in the Paraná River, studies on the population densities of $L$. fortunei are restricted to the lower (Boltovskoy and Cataldo, 1999; Boltovskoy et al., 2006; Darrigran et al., 2007; Sylvester et al., 2007) and upper sections (Dreher 
Mansur et al., 2003; Oliveira et al., 2006; Belz et al., 2010; Oliveira et al., 2010), with values above 250,000 ind. $\mathrm{m}^{-2}$. Furthermore, the available information about mollusc density on living substrates such as macrophytes is scarce and limited to the Paraguay River, the Upper Paraná basin and the Guaiba Lake (Dreher Mansur et al., 2003; Dos Santos et al., 2008; Marçal and Callil, 2008; Michelan et al., 2014).

Lakes associated with the Middle Paraná River usually present high densities of aquatic macrophytes, among which Eichhornia crassipes has the highest coverage, biomass and productivity (Carignan and Neiff, 1992; Poi de Neiff and Carignan, 1997; Poi de Neiff and Neiff, 2006). It usually forms cohesive floating meadows which may cover $20-100 \%$ of the surface of the waterbody (Poi de Neiff and Carignan, 1997). The root system of this macrophyte has different microhabitats that host great biological diversity (Paporello de Amsler, 1987; Poi de Neiff and Neiff, 2006; Sabattini and Lallana, 2007), including $L$. fortunei (Rojas Molina et al., 2010). Given the golden mussel's multiple interactions with local biota, information on its densities on these plants is necessary for assessing its potential and realized ecological impacts on benthic, planktonic, and nektonic organisms. Moreover, the association of this macrophyte (native to the Amazon basin which invaded Argentina by natural spread from the Mato Grosso along the Paraguay River; Barrett and Forno, 1982) with the golden mussel is particularly significant not only regionally, but also internationally. Both organisms are successful invasive species. During the last 150 years, E. crassipes has invaded several countries in almost every continent modifying the habitat as a result of its rapid growth and large biomass covering water surfaces and producing many harmful effects (Holm et al., 1977; Fitzsimons and Vallejos, 1986; Gopal, 1987; Meerhoff and Mazzeo, 2004).

Although the presence of the golden mussel on submerged stems and roots of aquatic vegetation has been noted in the Middle Paraná (Darrigran and Ezcurra de Drago, 2000; Darrigran, 2002; Rojas Molina et al., 2010), information on its densities on this substrate is restricted to a few ancillary data. The aim of this study was to characterize the population structure and density of Limnoperna fortunei associated to Eichhornia crassipes in lakes of the Middle Paraná River during a yearly cycle.

\section{METHODS}

\section{Study area}

The Paraná is the main river of the Río de la Plata Basin, containing $85 \%$ of the total freshwater in Argentina. The flow regime along the main channel has got the highest discharge rates and flooding of the associated floodplain in spring and summer (November to March), and lowest discharge rates in the autumn and winter (Bonetto and Wais, 1995; Giacosa et al., 2000). This regime generates a complex biological connectivity between the main channel and the floodplain, characterized by active lateral and longitudinal exchange of sediments, organic matter and organisms (Drago, 2007).

The Middle Paraná River is the section stretching 700 $\mathrm{km}$ upstream from the Paraguay River outlet into the Paraná to the apex of the Paraná delta, in the vicinity of Rosario city (Santa Fe province, Argentina). The mean annual flow is around $17,000 \mathrm{~m}^{3} \mathrm{~s}^{-1}$, reaching extreme records of 8000 and 60,000 $\mathrm{m}^{3} \mathrm{~s}^{-1}$ (Giacosa et al., 2000). Along its main channel, the Middle Paraná River has a floodplain with a surface of ca. 20,000 $\mathrm{km}^{2}$ (Paoli et al., 2000; Drago, 2007), hosting numerous permanent and temporary lentic water bodies densely populated by aquatic and palustrine plants and alluvial forests (Paira and Drago, 2007). In this floodplain, two lakes with different degrees of connection to the main channel of the Paraná River were selected: Irupé Lake $\left(31^{\circ} 40^{\prime} 22^{\prime \prime} \mathrm{W}\right.$, $\left.60^{\circ} 34^{\prime} 17^{\prime \prime} \mathrm{S}\right)$, indirectly connected with the river through secondary channels (Miní and Tiradero streams), and Miní Lake (3140'32”'W, 60³2'43”S), with a direct connection to the Paraná River (Fig. 1). These lakes present shorelines with free-floating, rooted emergent and submerged macrophytes like Eichhornia crassipes, E. azurea, Ludwigia peploides, Paspalum repens, Salvinia herzogii, Pistia strationes, Nymphoides indica, Myriophyllum sp., Ceratophyllum demersum, among which E. crassipes is the most abundant and frequent.

\section{Sampling and laboratory methods}

Monospecific floating meadows of $E$. crassipes were sampled monthly between November 2009 and November 2010 at three random points in each lake (Krebs, 1999). These sample points were spaced approximately $200 \mathrm{me}-$ ters apart and were maintained throughout the study. Floating plants were collected using a $0.385 \mathrm{~m}^{2}$ sampler (Capello, 2010). Each sample point was considered as a replicate. The plants collected were stored in plastic bags and brought to the laboratory for further processing.

At each sampling site the following environmental parameters were recorded: temperature, conductivity, dissolved oxygen and $\mathrm{pH}$ (Hanna ${ }^{\circledR}$ sensors); depth (hand-held echo sounder), and Secchi disk depth. Subsurface $(0.20 \mathrm{~m})$ water samples were filtered through Whatman GF/F glass microfiber filters to analyse nutrients and chlorophyll- $a$

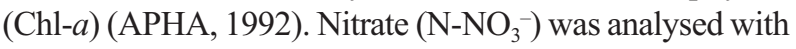
the cadmium-copper reduction method and soluble reactive phosphorus (SRP) with the ascorbic acid-molibdate method. For Chl- $a$ determination, pigments were extracted with $90 \%$ acetone and measured with spectrophotometer. Hydrometric levels of the Paraná River (Harbour of Paraná, $60^{\circ} 30^{\prime} 27.77^{\prime \prime} \mathrm{W}, 31^{\circ} 42^{\prime} 33.75^{\prime} \mathrm{S}$ ) were provided by the 
Meteorological Information Center (CIM-FICH-UNL). For the purposes of our analyses, data were pooled using two hydrologic phases: low-water period $(<2.50 \mathrm{~m})$, and highwater period ( $>3.50 \mathrm{~m})$ (Drago, 1989).

In the laboratory, roots were washed over a $250 \mu \mathrm{m}$ mesh screen and the materials retained were fixed with $10 \%$ formalin solution. Subsequently, the roots were screened under a binocular stereoscopic microscope in order to remove remaining attached molluscs. All bivalves were counted and measured (maximum valve length) with a digital caliper $( \pm 0.05 \mathrm{~mm})$. Mussels smaller than $2 \mathrm{~mm}$ were photographed and measured with the aid of the TPS Dig2 program (Rohlf, 2004). Finally, the roots were wetweighed, dried $\left(105^{\circ} \mathrm{C}\right)$ during 168 hours (Capello, 2010) and then weighed again in order to calculate their biomass $\left(\mathrm{g} \mathrm{m}^{-2}\right)$.

\section{Data analysis}

Mussel densities were estimated both as a function of the area sampled (ind. $\mathrm{m}^{-2}$ ), and as a function of the dryweight root biomass (ind. $\mathrm{g}^{-1}$ ).

Spearman rank correlation coefficients (Rho) (data transformations failed to fulfil the assumptions for parametric tests) were used to assess association between environmental variables, and between the latter and mollusc densities. Environmental parameters between lakes were compared by means of $\chi^{2}$ analyses, while bivalve densities and sizes were analysed by means of Mann-Whitney tests (U). Comparison of data through the sampling periods in each lake was performed using the non-parametric Friedman test. Between-lakes root biomass differences were assessed using the Student $t$-test. A Principal Component Analysis (PCA) was used to investigate relationships be- tween physicochemical and biological variables. All analyses were performed with the PAST software (Hammer et al., 2001).

To identify relationships between the density and the size of mussels and environmental variables, generalized linear models with randomization (GLM set as Gaussian distribution) were proposed to explain each variable (attempts to use multiple regression analyses failed because data did not fulfil the requirements of normality, homogeneity and independency). Multicollinearity problems were sorted taking into account correlations among variables, considering the variables with $r \geq 0.7$ of Pearson correlation as collinear. Also variance inflation factor (VIF) was considered to evaluate the multicollinearity over the model. GLM were applied to 5000 random permutations and to a type II ANOVA because of the unbalanced effect and no interactions variables were performed. The variables included in the models were: biomass, temperature, water level, SRP, nitrate, and Chl- $a$ as independent variables, and density and the size of mussels as dependent variables. For size variable, the GLM were run without biomass following a biological criterion of no relation of size with the mussels' size. Statistical tests were performed with R software ( $R$ Development Core Team, 2008).

\section{RESULTS}

\section{Environmental conditions}

The period of high waters was from December 2009 to June 2010, and the period of low waters from September to November 2010 (Fig. 2). Temperature, pH and Secchi disk values were similar between the lakes (Tab. 1). The maximum values of temperature and SRP coincided

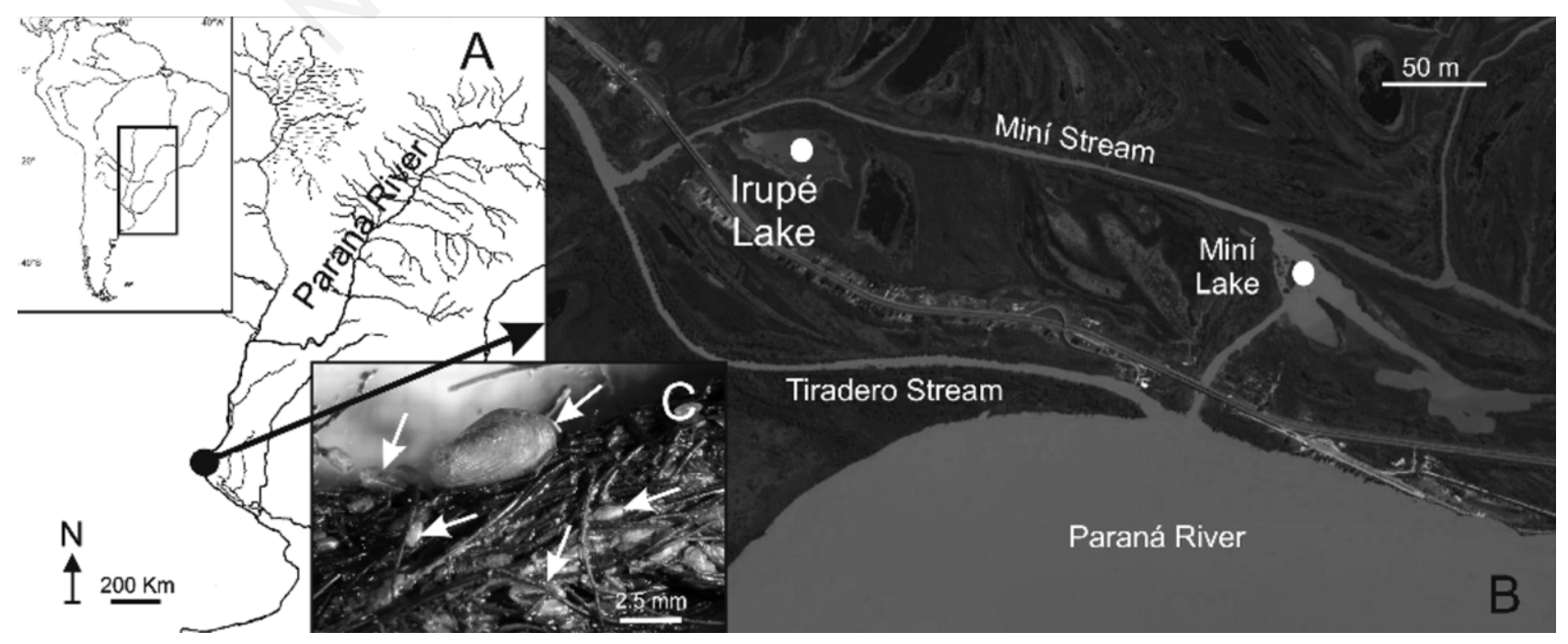

Fig. 1. Map of lakes sampled (A, B) and photograph of mussels attached to the roots of Eichhornia crassipes (C). 
with the high water phase while $\mathrm{pH}$, conductivity, dissolved oxygen and nitrate showed the lowest values in this period. During the low water phase these parameters showed a reverse trend. Transparency was positively correlated with the hydrometric level in both lakes (Miní: $\mathrm{Rho}=0.651 ; \mathrm{P}<0.001$; Irupé: $\mathrm{Rho}=0.895 ; \mathrm{P}<0.001$ ).

Concentrations of dissolved oxygen were negatively correlated with temperature in both lakes (Miní: Rho= 0.806 ; $\mathrm{P}<0.001$; Irupé: $\mathrm{Rho}=-0.912 ; \mathrm{P}<0.001)$. Conductivity was inversely and significantly correlated with hydrometric level (Miní Lake, Rho $=-0.755, \mathrm{P}<0.001$; Irupé Lake, $\mathrm{Rho}=-0.413, \mathrm{P}=0.021)$. Of the environmental parameters assessed, only SRP and nitrates differed significant between lakes (SRP, $\chi^{2}=31.901, \mathrm{P}=0.000416$; nitrate, $\left.\chi^{2}=135.2, \mathrm{P}=4.05 \mathrm{E}^{-24}\right)$.

\section{Density and size of molluses}

The average density of mussels in the Irupé Lake was $32.11( \pm 88.29)$ ind. $\mathrm{gr}^{-1}$ or $2765.90( \pm 7768.53)$ ind. $\mathrm{m}^{-2}$. These values were not significantly $(\mathrm{U}=333 ; \mathrm{P}=0.51)$ higher than those in the Miní Lake, $16.54( \pm 61.66)$ ind. $\mathrm{gr}^{-1}$ or $981.89( \pm 3190.87)$ ind. $\mathrm{m}^{-2}$. In both lakes mussel densities varied significantly over the period studied (Miní: $\chi^{2}=18.64, \mathrm{P}=0.009$; Irupé: $\chi^{2}=22.34, \mathrm{P}=0.008$ ), and no mussels were found in January (Miní Lake) and in March (both lakes). The highest densities were recorded in October and November 2010 in Irupé, and in November 2009 in Miní. The rest of the period presented densities $\leq 5$ ind $\mathrm{m}^{-2}$ and $\leq 1$ ind. $\mathrm{g}^{-1}$ in both lakes (Fig. 3). Variations in bivalve density were not related to changes in the biomass of $E$. crassipes roots (Miní: $\mathrm{Rho}=0.303$; $\mathrm{P}=0.087$; Irupé: $\mathrm{Rho}=-0.121 ; \mathrm{P}=0.517)$. In both lakes, the highest biomass of $E$. crassipes roots was recorded in January, when mussel densities were $<1$ ind. $\mathrm{g}^{-1}$, and the lowest biomass was recorded in April 2010 in Miní and in November 2010 in Irupé with densities $<1$ ind. $\mathrm{g}^{-1}$ and $>200$ ind. $\mathrm{g}^{-1}$, respectively (Fig. 3). In the Miní Lake, macrophytes were collected until July because of the absence of E. crassipes in the following months. Betweenlakes differences in root biomass were not statistically significant $(t=1.497 ; \mathrm{P}=0.1402)$. A total of 2006 individuals were measured in both lakes, over $60 \%$ of them being smaller than $5 \mathrm{~mm}$. The maximum size recorded was
$19.41 \mathrm{~mm}$ in the Miní Lake during November 2009, while the minimum was $0.20 \mathrm{~mm}$ in the Irupé Lake during October 2010. Mussel sizes differed significantly between lakes $(\mathrm{U}=366053 ; \mathrm{P}<0.0001)$, with larger specimens in the Miní Lake $(4.19 \pm 3.27 \mathrm{~mm})$, than in the Irupé Lake (2.89 $\pm 2.71 \mathrm{~mm}$ ) (Fig. 4).

In both lakes, the sizes of molluscs varied during the months studied (Irupé: $\chi^{2}=20.867 ; \mathrm{P}=0.008$; and Miní: $\left.\chi^{2}=17.733 ; \mathrm{P}=0.001\right)$. The last months of the period under study (July to November in Irupé and June to July in Miní) showed smaller organisms (average size between 1.3 and $2.6 \mathrm{~mm}$ ) than in the previous months (Fig. 5). The first two axes of the PCA summed up $63.57 \%$ of the variation of the sites and dates. The first component showed $47.47 \%$ of the variance and was positively related to the hydrometric level and the root biomass, and negatively linked to Chl- $a$ concentration. The second component accounted for $16.10 \%$ of data variation and was positively associated with temperature, conductivity and density, and negatively with dissolved oxygen, SRP and the sizes of the molluses. The pattern of distribution points in the diagram suggests the existence of groups which are related to the water level. Regardless of the sampled lakes, three

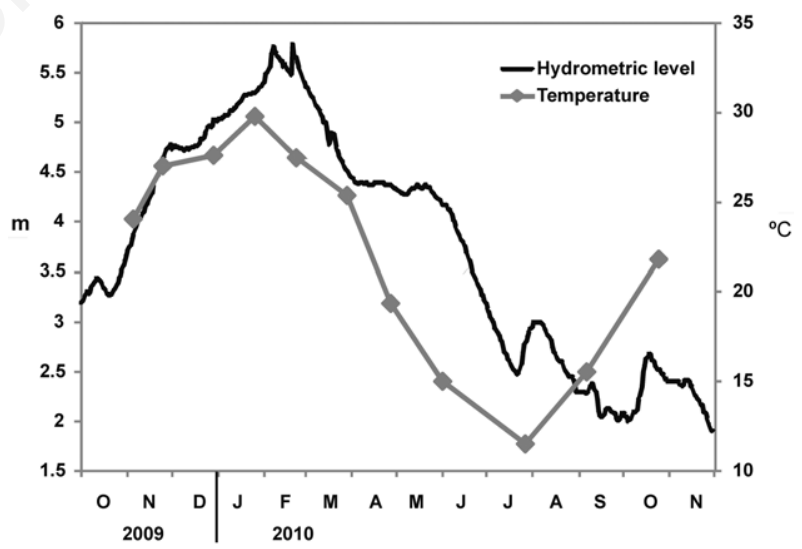

Fig. 2. Water level $(\mathrm{m})$ and temperature $\left({ }^{\circ} \mathrm{C}\right)$ variations during the period of study. Sampling dates coincide with the values of water temperature.

Tab. 1. Median values and range of environmental variables in the lakes.

\begin{tabular}{|c|c|c|c|c|c|c|c|c|c|}
\hline Lake & $\begin{array}{l}\text { Temp. } \\
\left({ }^{\circ} \mathrm{C}\right)\end{array}$ & $\begin{array}{l}\text { Secchi } \\
(\mathrm{m})\end{array}$ & $\begin{array}{l}\text { Depth } \\
\text { (m) }\end{array}$ & $\mathrm{pH}$ & $\begin{array}{l}\text { Conductivity } \\
\qquad\left(\mu \mathrm{S} \mathrm{cm}{ }^{-1}\right)\end{array}$ & $\begin{array}{l}\text { Dissolved oxygen } \\
(\mathrm{ppm})\end{array}$ & $\begin{array}{c}\text { SRP } \\
\left(\mu g L^{-1}\right)\end{array}$ & $\begin{array}{l}\mathrm{N}-\mathrm{NO}_{3} \\
\left(\mu g \mathrm{~L}^{-1}\right)\end{array}$ & $\begin{array}{c}\mathrm{Chl}-a \\
\left(\mathrm{mg} \mathrm{m}^{-3}\right)\end{array}$ \\
\hline Miní & $\begin{array}{c}22.3 \\
(12-29.5)\end{array}$ & $\begin{array}{c}0.6 \\
(0.2-1.4)\end{array}$ & $\begin{array}{c}2.9 \\
(0.7-5.7)\end{array}$ & $\begin{array}{c}6.6 \\
(6.2-7.4)\end{array}$ & $\begin{array}{c}60.4 \\
(48-73)\end{array}$ & $\begin{array}{c}6.5 \\
(2.2-10.2)\end{array}$ & $\begin{array}{c}87.5 \\
(58.6-120.6)\end{array}$ & $\begin{array}{c}360 \\
(200-700)\end{array}$ & $\begin{array}{c}4.2 \\
(1.3-8.6)\end{array}$ \\
\hline Irupé & $\begin{array}{c}21.9 \\
(11-30)\end{array}$ & $\begin{array}{c}0.6 \\
(0.2-1.3)\end{array}$ & $\begin{array}{c}3.4 \\
(1.3-4.8)\end{array}$ & $\begin{array}{c}6.7 \\
(6.3-7.3)\end{array}$ & $\begin{array}{c}60.9 \\
(45-75.1)\end{array}$ & $\begin{array}{c}5.9 \\
(2.1-10.9)\end{array}$ & $\begin{array}{c}87 \\
(48.9-120.6)\end{array}$ & $\begin{array}{c}350 \\
(200-500)\end{array}$ & $\begin{array}{c}5.7 \\
(0.8-11.1)\end{array}$ \\
\hline
\end{tabular}

$S R P$, soluble reactive phosphorus. 
groups of data were formed: the first group was associated to the beginning of the rising and high water periods, the second was associated to the lowering of water and the third one was related to the low water period (Fig. 6).

According to the GLM proposed, density accounted for by temperature, Nitrate and Chl- $a$, the model explain the $20.88 \%$ of variability (Tab. 2). Size was explained by SRP, the model explain the $12.73 \%$ of variability (Tab. 3 ).

\section{DISCUSSION}

Despite the hydrometric level variation during the period of study, neither of the two lakes was disconnected from the main channel. Analysis (PCA) revealed that the two lakes under study remained spatially alike despite having different degrees of connection to the main channel. However, the temporal variation had a greater weight in the grouping of the sampling points. This exploratory analysis gives evidence that the pooling of data was adjusted to the dynamics of the hydrometric levels. In addition, the limnological variable at each site reflects the effect of the hydrosedimentological pulse.

In this section of the Paraná River, during the rising and inundation phases, the flood water first enters the floodplain through the floodplain channels, and then by overflowing the levees. Then, when the inundation phase ends, the waters begin to decline, establishing a drainage

Tab. 2. Analysis of deviance table (Type II tests). Response: density.

\begin{tabular}{lcccc} 
LR & Chisq & df & Pr $(>$ Chisq) & $\begin{array}{c}<\text { Permutation } \\
(5000)\end{array}$ \\
Biomass & 1.1468 & 1 & 0.2842 & 0.2952 \\
Temperature & 5.2048 & 1 & $0.022525 *$ & 0.0276 \\
\hline Phosphorus & 0.9202 & 1 & 0.337419 & 0.3482 \\
Nitrate & 4.5414 & 1 & $0.033084 *$ & 0.0332 \\
\hline Chl- $a$ & 10.6743 & 1 & $0.001086 * *$ & 0.0022 \\
\hline
\end{tabular}

$d$, degree of freedom; $* * P<0.001, * P<0.01$.

Tab. 3. Analysis of deviance table (Type II tests). Response: size.

\begin{tabular}{lcccc} 
LR & Chisq & df & $\operatorname{Pr}(>$ Chisq) & $\begin{array}{c}\text { Permutation } \\
(5000)\end{array}$ \\
$\begin{array}{l}\text { Temperature } \\
\text { Hydrometric }\end{array}$ & 0.5937 & 1 & 0.44101 & 0.4392 \\
\hline level & 0.9379 & 1 & 0.33281 & 0.3288 \\
Phosphorus & 3.7896 & 1 & $0.05157^{*}$ & 0.051 \\
\hline Nitrate & 0.1560 & 1 & 0.69284 & 0.6892 \\
Chl- $a$ & 0.5032 & 1 & 0.47810 & 0.4742 \\
\hline
\end{tabular}

$d f$, degree of freedom; $* P<0.05$. from the floodplain lakes to the channels (Drago 1981, 2007). Nevertheless, in a study carried out by Mesa et al. (2012) in the Miní Lake it was found that during the period of high water the flow drifted from the floodplain to the main channel, whereas during the low water period it occurs in the opposite direction, without coinciding this with the description given previously. This situation may explain the lack of vegetation in the Miní Lake in subsequent months of July considering that the floating meadows could be flushed out of the lake. The drift of the aquatic vegetation in floating meadows produced by the flood pulse and weather factors makes organic matter and organisms flow from one place to another in the ecological system (Sabattini and Lallana, 2007).

Our results indicate that the temporal changes in densities of $L$. fortunei associated with E. crassipes were similar in both lakes. Bivalve densities showed an important
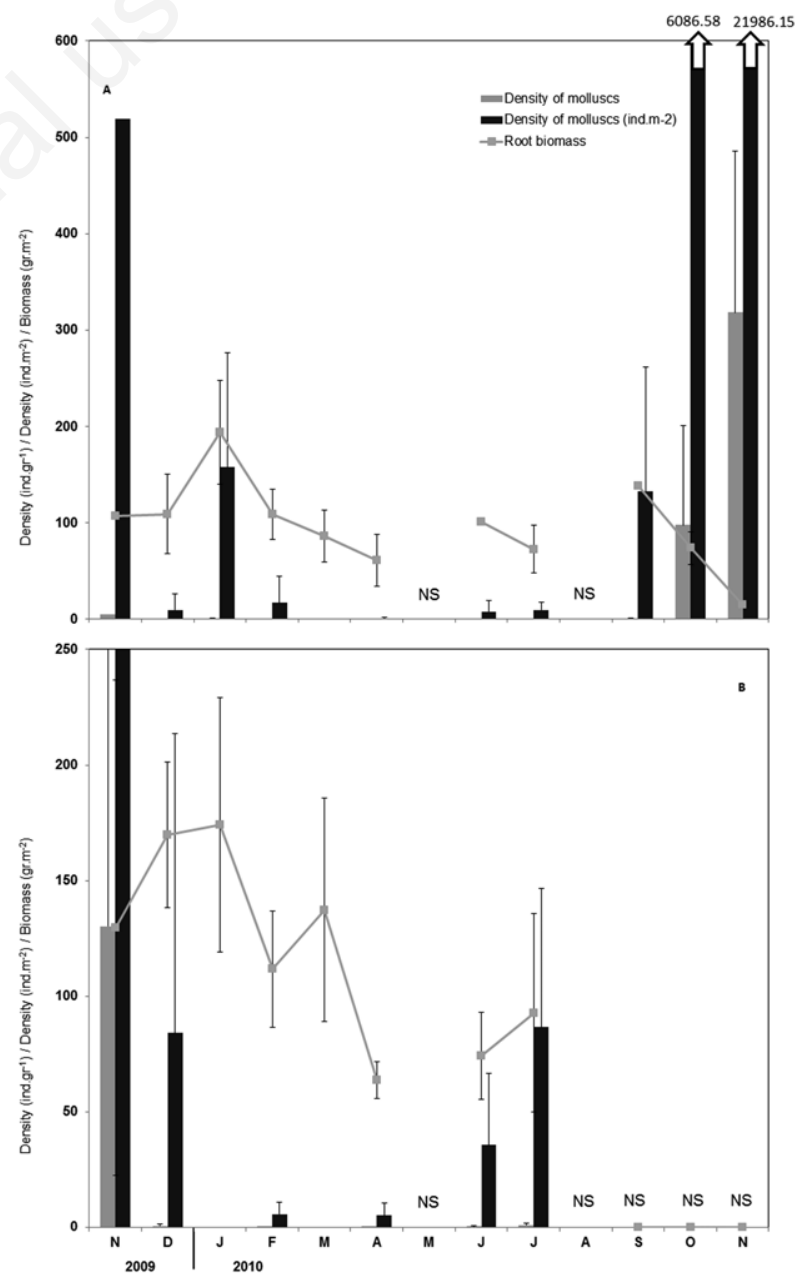

Fig. 3. Densities of L. fortunei (ind. $\mathrm{gr}^{-1}$ and ind. $\mathrm{m}^{-2}$ ) and root biomass $\left(\mathrm{gr} \mathrm{m}^{-2}\right)$ during the period of study in Irupé (A) and Miní (B) lakes. NS: no sample. 
A

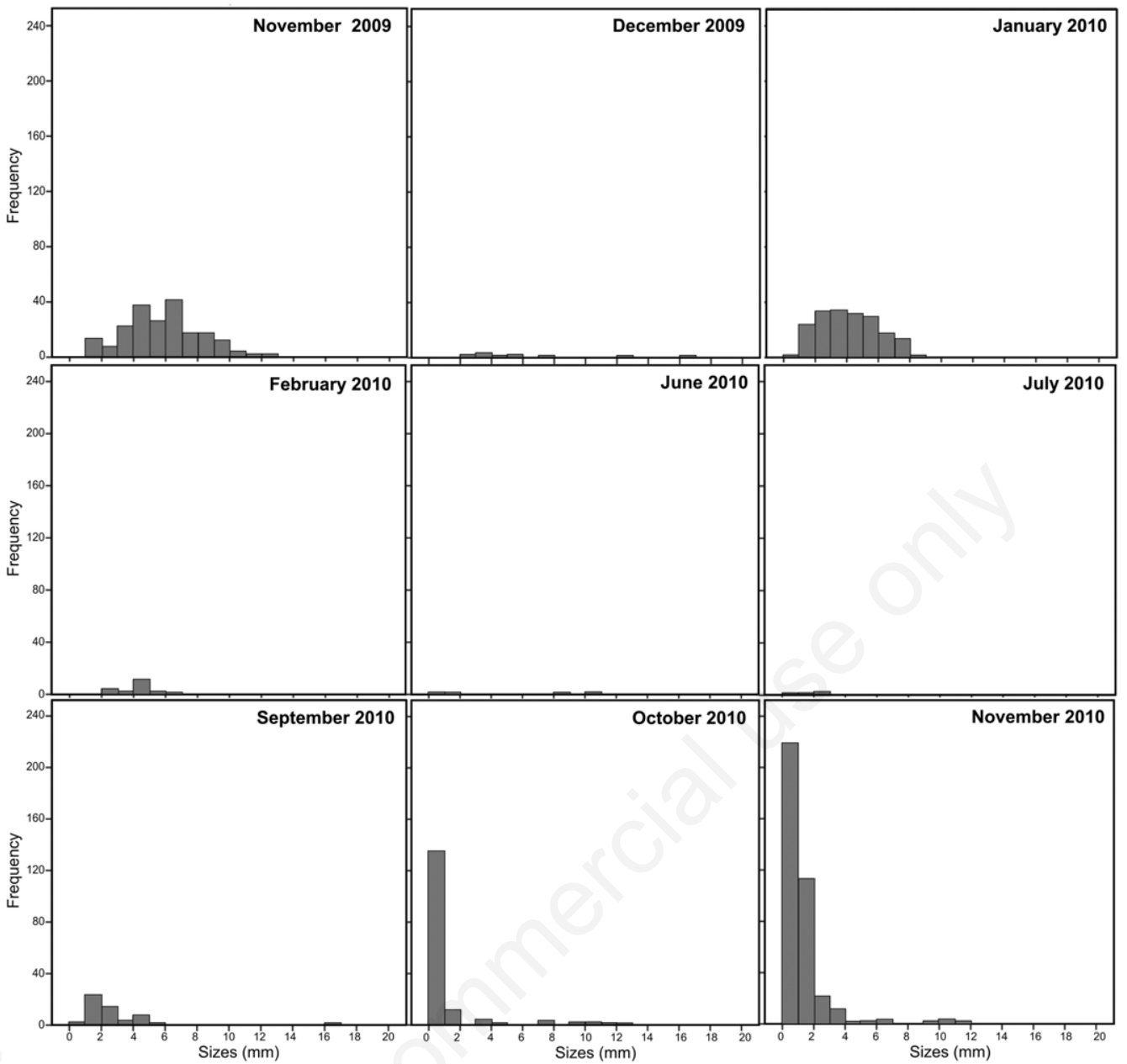

B
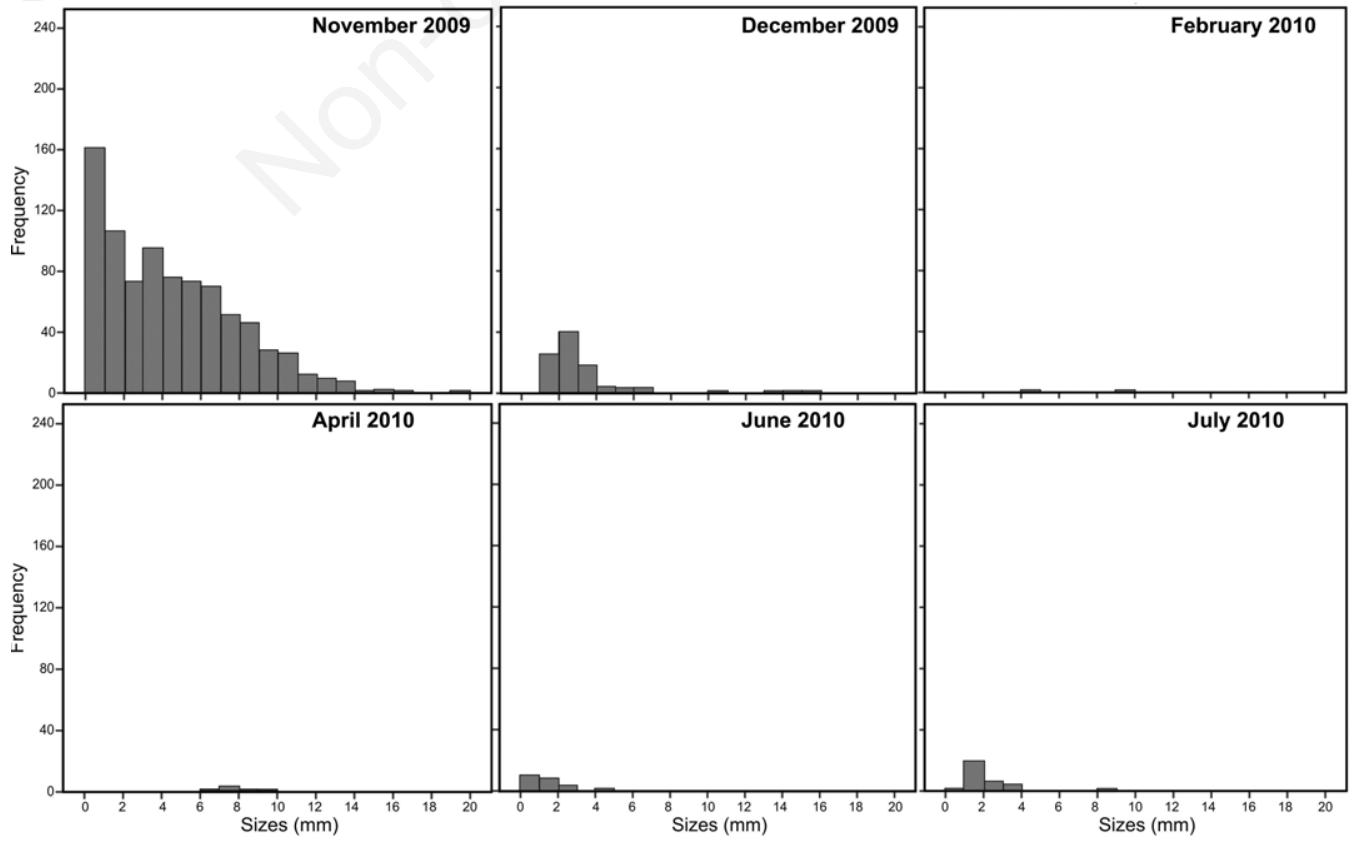

Fig. 4. Monthly mollusc size distribution registered for Irupé (A) and Miní (B) lakes during all the period of study. 
variation in values which were associated with the water temperature. High density peaks were recorded during months with high temperature (September, October and November) when population was characterized by a high proportion of small size organisms, less than $5 \mathrm{~mm}$ in length. The largely domination by small recruits could be related to the reproductive periods of the mollusc. In the main and secondary channels in the Middle Paraná River, the seasonal variation in the number of larvae of $L$. fortunei is associated with water temperature, with the highest larval densities in seasons with high water temperatures (September to April) (Ezcurra de Drago et al., 2006; Rojas Molina and José de Paggi, 2008; Rojas Molina et al., 2014).

Regarding the absence of mussels in January and March, the fact that no mussels were recorded does not mean that there were no organisms there. This absence of records could be due to the effect of a random sampling of macrophytes. Moreover, the presence of $L$. fortunei's freeliving planktonic larvae during these months in Irupé Lake and in other neighbouring lakes (about 45.7 ind. $\mathrm{L}^{-1}$; Carvalho, 2014) suggests that there is an area populated by reproductive adult mussels in or near the sampling point. The nonstop connectivity of these lentic environments surrounded by lotic environments could favors the drift towards these lakes of planktonic larvae produced by adults established mainly in lotic environments.

There are several records that report variable $L$. fortunei densities on natural and artificial substrates. In the present study, the densities recorded were lower than the values obtained in inert and hard substrates in the lower and upper Paraná River and in the Río de La Plata River (from 22,000 to 250,000 ind. $\mathrm{m}^{-2}$; Boltovskoy and Cataldo, 1999; Sylvester et al., 2007; Belz et al., 2010; Bonel, 2011; Spaccesi, 2013, among others). In spite of these last values are dominated by small recruits (over $70 \%$ of the mussels below $1 \mathrm{~mm}$ in length) due to seasonal changes in density through the year, the abundance of adults are much higher than in the present study. It is likely that the differences between the latter studies and this work are mainly associated with the type of substrate. The rough surface of natural (rocks, boulders, wood debris) and man-made structures (PVC frames, pipes, docks, and walls) which are available in hard substrates are more stable and permanent in the environment, and this could be beneficial for the settlement and the growth of the golden mussel, favouring the development of dense mussel beds on hard substrates.

Conversely, this may not be likely to occur with the flexible filament roots of $E$. crassipes due to a greater length-weight ratio of the mussel that exceeds the supporting capacity of the substrate favouring their detachment. In addition, this macropyte is seasonal and lacks long term stability. During the cold season and if there is a sharp frost, stands of E. crassipes will die (Lallana, $1980,1981)$ and the attached molluscs will fall to the bottom with necromass as was observed for bivalves associated with coarse particulate organic matter in several water bodies in the Middle Paraná area (Montalto and Rojas Molina, 2014). Other possibility could be the abandonment of the senescent plants as was observed for Dreissena polymorpha (freshwater mussel that invaded North America). Bodamer and Ostrofsky (2010) found that juvenile $D$. polymorpha leave their attachment to Nuphar stems as a consequence of a deterioration of substrate quality to the mussel. There are some studies about the decomposition of Eichhornia that point out a high loss of allelochemicals (polyphenols) which can benefit or harm the surrounding organisms (Roland et al., 1990; Stripari and Henry, 2002). However, this has not yet been studied with L. fortunei. Another factor that should be considered for the low mussel density is that stands of this

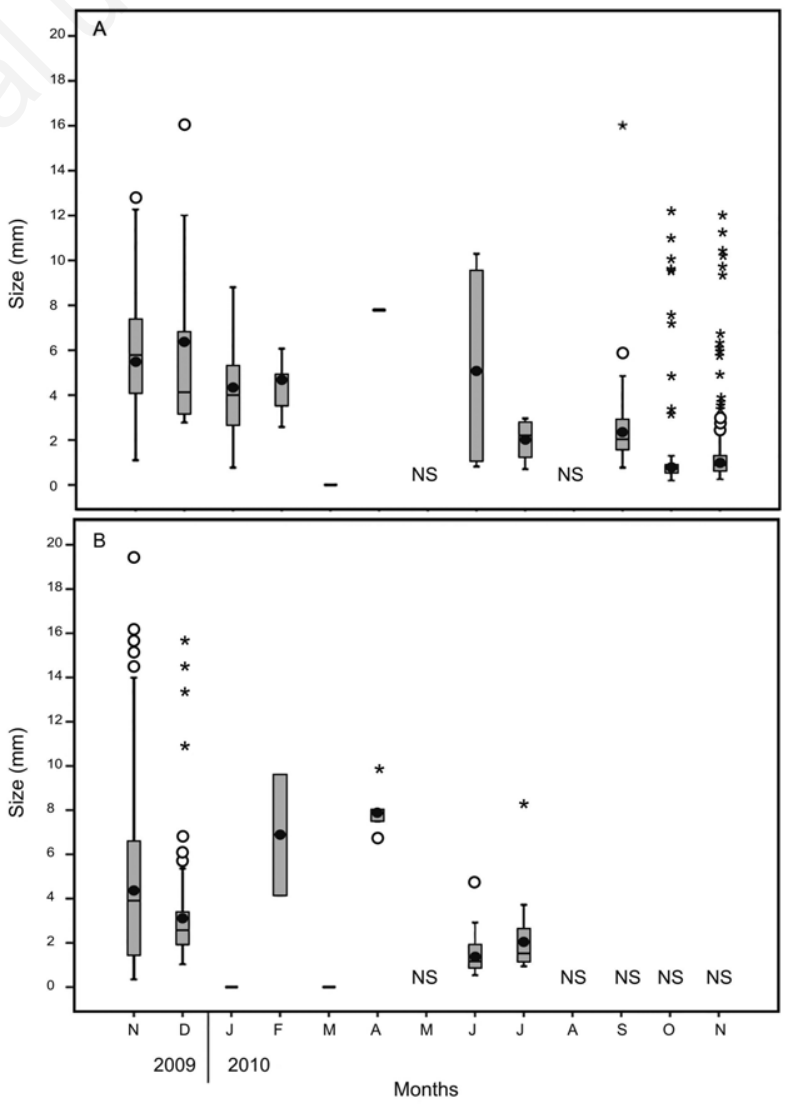

Fig. 5. Mollusc size distribution registered for Irupé (A) and Miní (B) lakes in each month. Outer lines are the $95^{\text {th }}$ percentiles; upper and lower boundaries of the box are the $90^{\text {th }}$ percentiles; the horizontal line and the black circle in the box interior are the median and mean values, respectively. White circles and asterisks are atypical and extreme values, respectively. 
macrophyte could be dragged in the flooding period and replaced by others that have not been colonized by $L$. fortunei, thus having an unstable substrate for the establishment of large colonies.

Nevertheless, the average densities recorded in the present study were similar and/or greater than those obtained for aquatic macrophytes in other environments of the Río de la Plata basin. A case in point is that of lakes connected to the Upper Paraguay River, in which the density of $L$. fortune $i$ associated with $E$. crassipes varied from 7 to 1205 ind. $\mathrm{m}^{-2}$ (Marçal and Callil, 2008), and 0 to 82.44 ind. $\mathrm{g} \mathrm{dw}^{-1}$ (Michelan et al., 2014). Another instance is the work done in the Guaíba Lake Basin (southern of Brazil), where the maximum density of $L$. fortunei in E. crassipes roots was 0.37 ind. gr ${ }^{-1}$ (Dreher Mansur et al., 2003). The mean values of density should be analysed considering the large deviations arising from the dynamics recorded in populations of $L$. fortunei (few months with high density and several months with few records).

Concerning the bivalve size which was based on previous studies (Maroñas et al., 2003), the maximum size recorded in both lakes $(19.41 \mathrm{~mm})$ corresponded to individuals of approximately 2.5 years old; however, up to $75 \%$ of the molluscs was represented by pre-reproductive individuals ( $<5 \mathrm{~mm}$, up to 6 months old; Maroñas et al., 2003). In comparison, larger individuals were registered in studies carried out with $L$. fortunei attached to inert hard substrates (30 to $40 \mathrm{~mm}$; Boltovskoy and Cataldo, 1999; Darrigran and Damborenea, 2011; Spaccesi, 2013) than bivalves recorded in association with the vegetation roots in these lakes. Several reasons could explain the fact that mussels older than $5 \mathrm{~mm}$ are scarce in the macrophyte roots. Some of them are related to the Eichhornia dynamics and were outlined above for mussel density. For example, the flushed out of the lakes of the colonized plant and the mortality of the plants during the cold season may be sufficient to limit the size of $L$. fortunei. Moreover, some predators, like crabs and fish, may have a preference for a specific size range of the mussel. Some freshwater crabs that frequent $E$. crassipes as refuges and feeding sites (e.g., Zilchiopsis collastinensis and Trichodactylus borellianus), are capable of consume on L. fortunei and make a size selective predation (Torres et al., 2012; Manso, 2015). The consume of golden mussel by fish has been well documented and constitutes an important part of the intake of several fish species in the Middle Paraná River, mainly bivalves up to $15 \mathrm{~mm}$. (Montalto et al., 1999; Garcia and Montalto, 2006).

According to this we can say that the roots of $E$. crassipes are an important available substrate for $L$. fortunei, especially during its early stages of development. This coincides with the work done by Ohtaka et al. (2011) in an inland lake in Cambodia, Southeast Asia, where they also found small $L$. fortunei $(1.96-12.7 \mathrm{~mm})$ attached only to

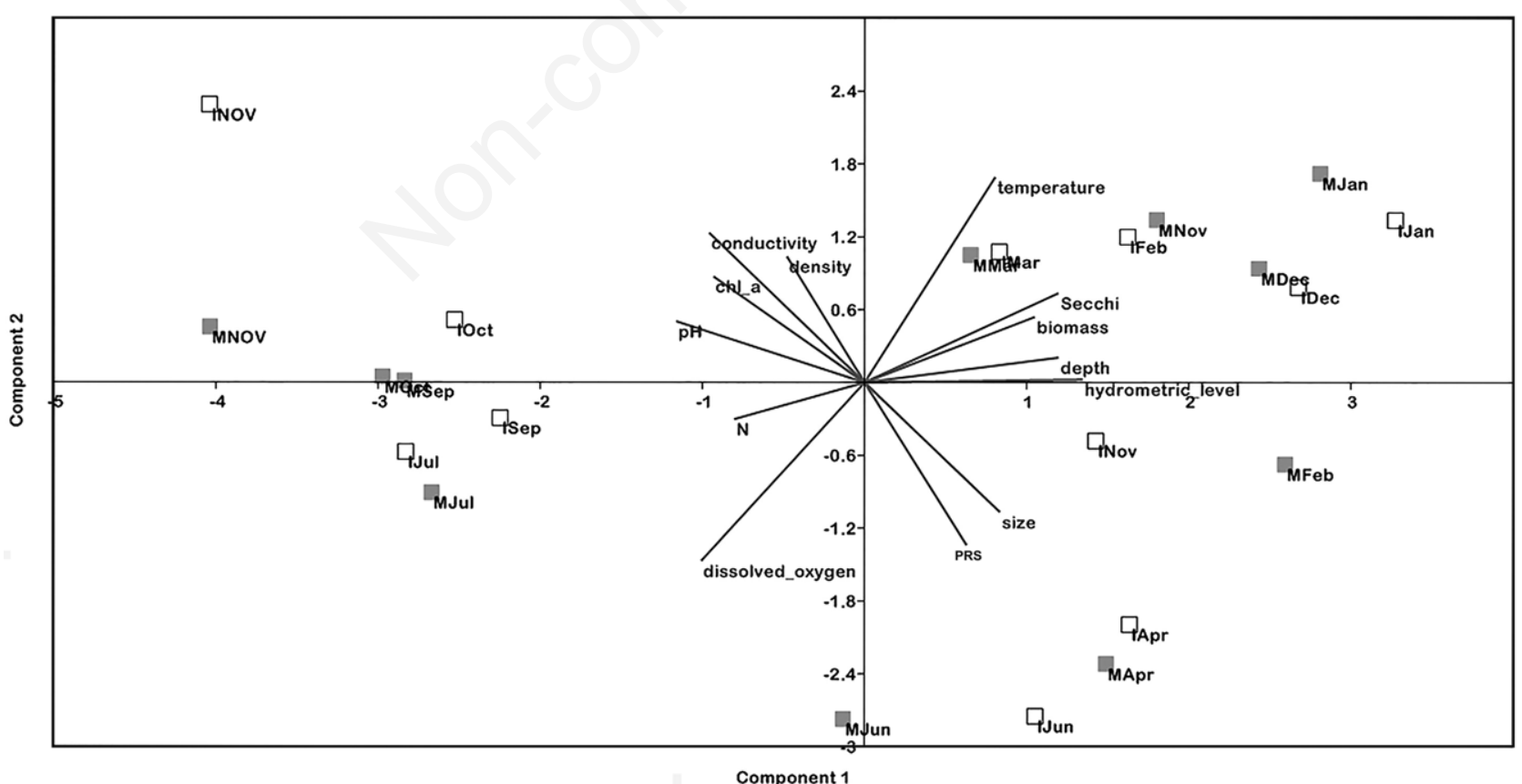

Fig. 6. First and second axes of PCA based on environmental variables, density and size of molluscs. Each vector is represented with lines and samples with a symbol (full square: Miní Lake; empty square: Irupé Lake) and the corresponding month abbreviated with the beginning letters (NOV corresponds to November 2010). 
E. crassipes roots even though there were other macrophytes available. Several studies have demonstrated the importance of filamentous substrates such as aquatic macrophytes and filamentous algae in the settlement of larvae and juveniles of marine and freshwater bivalve species (Bayne, 1964; Ackerman et al., 1994; CáceresMartínez et al., 1994; Harvey et al., 1995; Folino-Rorem et al., 2006). Dreissena polymorpha pediveligers have shown to prefer filamentous substrates, such as aquatic plants (Lewandowski, 1982). Folino-Rorem et al. (2006), in a settlement study found that individuals of $D$. polymorpha attached to artificial filaments were significantly smaller in size than mussels attached to control surface plates. There was a greater settlement of mussel larvae on plates with attached filaments than on plates without filaments. However, it is claimed that this did not happen as a matter of preference but by an increase in the total surface area available. No research on $L$. fortunei has been done yet to assess the preference between filamentary and rigid substrate at different life stages.

In the soft bottom of the habitats we studied, there is a scarcity of hard substrates and E. crassipes is among the few natural substrates that provides an alternative attachment site for $L$. fortunei and thus facilitates the dispersion of the mussel to other environments of the floodplain and in the basin. In inland lakes of the North hemisphere where are limited natural hard substrates a significant portion of the annual $D$. polymorpha settlement occurs on plant surfaces (stems, foliage and roots of emergent, submersed and floating macrophyte) (Lewandowski, 1982; Bodamer and Ostrofsky, 2010). Therefore, we should also take into consideration that the structure and floating way of life of $E$. crassipes facilitate the feeding of the bivalves by the filtering of planktonic microorganisms and particles (Rojas Molina et al., 2010). Considering the dynamics that the vegetation suffers during the hydrological regime (Sabattini and Lallana, 2007), the movements of these floating meadows may favour the dispersion of these organisms and could provide them with new opportunities for their settlement on hard substrates which are more rigid and fixed. In these last types of substrates adult populations can establish. Taking into account the data reported here and that $40 \%$ of the floodplain area of Middle Paraná is covered by lakes (Paira and Drago, 2007), it would be possible to calculate the mussel density for the entire area. However, to extrapolate this information it would be risky because it is necessary to have information about the population dynamics of $L$. fortunei in lakes with different connectivity and distance from channels that provide larvae.

Bearing in mind the mussel size recorded in the roots, the presence of $L$. fortunei on $E$. crassipes is limited to short periods of time therefore it can be estimated that this substrate could not be the final site of settlement for the golden mussel during its lifecycle. According to the background of D. polymorpha and other bivalves, the establishment of the mussel occurs in two phases: in the first one, the settlement of pediveliger larvae occurs together with their subsequent metamorphosis while in the second phase, the relocation of mussels to new areas happens during plantigrade, juvenile or adult (Ackerman et al., 1994). In laboratory experiments juveniles $D$. polymorpha abandoned the senesced stems and migrated to firm substrates (Bodamer and Ostrofsky, 2010). Furthermore, Uryu et al. (1996) have found that under experimental conditions juvenile and adult organisms of $L$. fortunei have the ability to move and resettle in new locations in case they have to face some disturbance (manipulation). In particular, they highlighted that mussels with a smaller size are highly adaptable to searching appropriate places, re-settling and binding tightly to the substrate immediately after release.

As previously mentioned, the relationship between $L$. fortunei and $E$. crassipes must be considered because in countries where these species are non-native, this association may be synergistic. This means that the impact of the two species could be greater than the sum of the impacts of the individual species, an effect of invasional meltdown according to the theory proposed by Simberloff and Von Holle (1999). Considering that E. crassipes provides adequate colonization sites for the mussel, and has invaded other countries that $L$. fortunei may invade or has already invaded (e.g., Cambodia), in all likelihood this could be an instance of invasional meltdown, as already proposed by Rojas Molina et al. (2010). In the Upper Paraná basin, Michelan et al. (2014) found that the invasive submersed aquatic macrophyte, Hydrilla verticillata, enhances the presence of Limnoperna fortunei in several water bodies in Brazil. The length, density and biomass are higher in the mussel attached to the invasive macrophyte than to the native macrophytes.

\section{CONCLUSIONS}

On the basis of our results, none of the measured environmental parameters seems limiting for the survival of Limnoperna fortunei populations. The registered temporal changes in densities of the mussels were similar in the studied lakes with different connection to the Middle Paraná River main channel. Roots of Eichhornia crassipes can host large number of individuals of $L$. fortunei, however the presence of the mussel is limited to short periods. The records of high densities of young individuals $(<5 \mathrm{~mm}$ in size) are closely related to the reproductive period of the golden mussel. It is estimated that in these lakes with soft bottom and limited hard substrates E. crassipes is an important site for the mussel attachment during its early stages of development and could not be the final site of settlement during its lifecycle.

Finally, we consider it necessary to continue doing ex- 
tensive research into the dynamics of the golden mussel population by means of a comprehensive study which should include a longer period of time as well as different substrates and environments. Thus, we would be able to learn more about invasion dynamics of this mussel and also to estimate the magnitude of the actual impact this species has on the biota within a system such as the Paraná River.

\section{ACKNOWLEDGMENTS}

We thank Gisela Mayora for the nutrient data provided. This study was supported by CAI+D 2009 PJ 14082, CAID+D 2011 PI 119 and Instrumento 2.1 (SECTEI) 2010-042-13.

\section{REFERENCES}

Ackerman JD, Blair S, Claudi R, 1994. A review of the early life history of zebra mussels (Dreissena polymorpha): comparisons with marine bivalves. Can. J. Zool. 72:1169-1179.

APHA, 1992. Standard methods for the examination of water and wastewater. American Public Health Association, Washington, DC, USA: $1100 \mathrm{pp}$.

Barrett SCH, Forno IW, 1982. Style morph distribution in new world populations of Eichhornia crassipes (Mart.) SolmsLaubach (water hyacinth). Aquat. Bot. 13:299-306.

Bayne BL, 1964. Primary and secondary settlement in Mytilus edulis L. (Mollusca). J. Anim. Ecol. 33:513-523.

Belz CE, Darrigran G, Bonel N, Máder Netto OS, 2010. Density, recruitment and shell growth of Limnoperna fortunei (Mytilidae), an invasive mussel in tropical South America. J. Freshwater Ecol. 25:227-233.

Bodamer BL, Ostrofsky ML, 2010. The use of aquatic plants of the zebra mussel (Dreissena polymorpha) (Bivalvia: Dreissenidae) in a small glacial lake. Nautilus 124:100-106.

Boltovskoy D, Cataldo D, 1999. Population dynamics of Limnoperna fortunei, an invasive fouling mollusc in the lower Paraná River (Argentina). Biofouling 14:255-263.

Boltovskoy D, Correa N, 2015. Ecosystem impacts of the invasive bivalve Limnoperna fortunei (golden mussel) in South America. Hydrobiologia 746:81-95.

Boltovskoy D, Correa N, Cataldo D, Sylvester F, 2006. Dispersion and ecological impact of the invasive freshwater bivalve Limnoperna fortunei in the Río de la Plata watershed and beyond. Biol. Invasions 8:947-963.

Boltovskoy D, Karatayev A, Burlakova L, Cataldo DH, Karatayev V, Sylvester F, Mariñelarena A, 2009. Significant ecosystemwide effects of the swiftly spreading invasive freshwater bivalve Limnoperna fortunei. Hydrobiologia 636:271-284.

Bonel N, 2011. [Demografía experimental de un bivalvo invasor, Limnoperna fortunei (Dunker, 1857), en la Cuenca del Plata].[PhD Thesis in Spanish]. Facultad de Ciencias Naturales y Museo, Universidad Nacional de La Plata, Argentina: $182 \mathrm{pp}$.

Bonetto AA, Wais IR, 1995. Southern South American streams and rivers, p. 257-293. In: C.E. Cushing, K.W. Cummins and G.W. Minshall (eds.), River and stream ecosystems of the world. Elsevier.
Cáceres-Martínez JJ, Robledo JA, Figueras A, 1994. Settlement and post-larvae behavior of Mytilus galloprovincialis: field and laboratory experiments. Mar. Ecol. Prog. Ser. 112:107117.

Capello S, 2010. [Caracterización de las comunidades de ortópteros y evaluación del efecto de consumo sobre los camalotales de diferentes ambientes leníticos en la llanura aluvial del río Paraná Medio].[PhD Thesis in Spanish].Facultad de Ciencias Naturales y Museo, Universidad Nacional de La Plata, Argentina: 210 pp.

Carignan R, Neiff JJ, 1992. Nutrient dynamics in the floodplain ponds of the Paraná River (Argentina) dominated by Eichhornia crassipes. Biogeochemistry 17:85-121.

Carvalho DA, 2014. [Tramas tróficas y régimen hidrosedimentológico en el valle de inundación del río Paraná medio: el cangrejo Trichodactylus borellianus como modelo de estudio].[PhD Thesis in Spanish]. Facultad de Bioquímica y Ciencias Biológicas, Universidad Nacional del Litoral, Argentina: $258 \mathrm{pp}$.

Correa N, Sardiña P, Perepelizin P, Boltovskoy D, 2015. Limnoperna fortunei colonies: structure, distribution and dynamics, p. 119-143. In: D. Boltovskoy (ed.) Limnoperna fortunei: the ecology, distribution and control of a swiftly spreading invasive fouling mussel. Springer, Berlin.

Darrigran G, 2002. Potential impact of filter-feeding invaders on temperate inland freshwater environments. Biol. Invasions 4:145-156.

Darrigran, G, 2010. Summary of the distribution and impact of the golden mussel in Argentina and neighboring countries, p. 389-396. In: R. Claudi and G. Mackie (eds.), Practical guide for the monitoring and control of aquatic invasive molluscs in freshwater systems. Taylor and Francis.

Darrigran G, Ezcurra de Drago I, 2000. [Distribución de Limnoperna fortunei (Dunker, 1857) (Mytilidae), en la Cuenca del Plata, Región Neotropical].[Article in Spanish]. Med. Amb. 13:75-79.

Darrigran G, Damborenea C, 2011. Ecosystem Engineering Impact of Limnoperna fortunei in South America. Zool. Science 28:1-7.

Darrigran G, Damborenea C, Drago EC, Ezcurra de Drago I, Paira A, Archuby F, 2012. Invasion process of Limnoperna fortunei (Bivalvia: Mytilidae): the case of Uruguay River and emissaries of the Esteros del Iberá Wetland, Argentina. Zoologia 29:531-539.

Darrigran G, Damborenea C, Greco N, 2007. Freshwater invasive bivalves in man-made environments: a case study of larvae biology of Limnoperna fortunei in a hydroelectric power plant in South America. AMBIO 36:575-579.

Darrigran G, Martin SM, Gullo B, Armendáriz L, 1998. Macroinvertebrates associated to the byssus of Limnoperna fortunei (Dunker, 1857) (Pelecipoda, Mytilidae) Río de la Plata, Argentina. Hydrobiologia 367:223-230.

Darrigran G, Penchaszadeh P, Damborenea C, Greco N, 2003. Abundance and distribution of golden mussel Limnoperna fortunei larvae in a hydroelectic power plant in South America, p. 312-316. Proceeding $11^{\text {th }}$ Int. Conf. on Aquatic Invasive Species, Alexandria, VA, USA.

Dos Santos CP, Dreher Mansur MC, Würdig NL, 2008. [Variações no comprimento dos indivíduos de uma população do mexilhão dourado, Limnoperna fortunei (Mollusca: Bi- 
valvia: Mytilidae), ao longo do ano, na praia do Veludo, Lago Guaíba, Rio Grande Do Soul, Brasil].[Article in Portuguese]. Rev. Bras. Zool. 25:389-396.

Drago E, 1981. [Grados de conexión y fases hidrológicas en ambientes leníticos de la llanura alluvial del río Paraná (Argentina)]. [Article in Spanish]. Ecología Argentina 6:27-33.

Drago E, 1989. Morphological and hydrological characteristics of the floodplain ponds of the Middle Paraná River (Argentina). Rev. Hydrobiol. Trop. 22:183-190.

Drago E, 2007. The physical dynamics of the river-lake floodplain system, p. 83-122. In: M.H. Iriondo, J.C. Paggi and M.J. Parma (eds.), The Middle Paraná River: limnology of a subtropical wetland. Springer, Berlin.

Dreher Mansur MC, Pinheiro dos Santos C, Darrigran G, Heydrich I, Callil C, Rossoni Cardoso F, 2003. [Primeiros dados quali-quantitativos do mexilhão-dourado, Limnoperna fortunei (Dunker), no Delta do Jacuí, no Lago Guaíba e na Laguna dos Patos, Rio Grande do Sul, Brasil e alguns aspectos de sua invasão no novo ambiente].[Article in Portuguese]. Rev. Bras. Zool. 20:75-84.

Ezcurra de Drago I, Montalto L, Oliveros O, 2006. [Desarrollo y ecología larval de Limnoperna fortunei, p. 83-91]. In: G. Darrigran and C. Damborenea (eds.) [Bio-invasión del mejillón dorado en el continente americano].[Book in Spanish]. Editorial de la Universidad de La Plata, Argentina.

Fitzsimons RE, Vallejos RH, 1986. Growth of water hyacinth (Eichhornia crassipes (Mart.) Solms) in the middle Paraná River (Argentina). Hydrobiologia 131:257-260.

Folino-Rorem N, Stoeckel J, Thorn E, Page L, 2006. Effects of artificial filamentous substrate on zebra mussel (Dreissena polymorpha) settlement. Biol. Invasions 8:89-96.

Garcia M, Montalto L. 2006. [Los peces depredadores de Limnoperna fortunei en los ambientes colonizados, p. 113129]. In: G. Darrigran and C. Damborenea (eds.) [Bio-invasión del mejillón dorado en el continente americano].[Book in Spanish]. Editorial de la Universidad de La Plata, Argentina.

Giacosa R, Paoli C, Cacik P, 2000. [Conocimiento del régimen hidrológico, p. 69-104]. In: C. Paoli and M. Schreider (eds.) [El río Paraná en su tramo medio. Contribución al conocimiento y prácticas ingenieriles en un gran río de llanura].[Book in Spanish]. Centro de Publicaciones, Secretaría de Extensión, UNL, Santa Fe, Argentina.

Gopal B, 1987. Water hyacinth. Elsevier, Amsterdam.

Hammer Ø, Harper DAT, Ryan PD, 2001. PAST: Paleontological statistics software package for education and data analysis. Palaeontologia Electronica 4:9.

Harvey M, Bourget E, Ingram RG, 1995. Experimental evidence of passive accumulation of marine bivalve larvae on filamentous epibenthic structures. Limnol. Oceanogr. 40:94-104.

Holm LG, Plucknett DL, Pancho JV, Herberger JP, 1977. The world's worst weeds: distribution and biology. University Press of Hawaii, Honolulu.

Karatayev A, Boltovskoy D, Padilla D, Burlakova L, 2007. The invasive bivalves Dreissena polymorpha and Limnoperna fortunei: parallels, contrasts, potential spread and invasion impacts. J. Shellfish Res. 26:205-213.

Krebs CJ, 1999. Ecological methodology. Benjamin-Cummings: $620 \mathrm{pp}$.

Lallana VH, 1980. [Productividad de Eichhornia crassipes
(Mart.) Solms. en una laguna isleña de la cuenca del río Paraná Medio. II. Biomasa y dinámica de población].[Article in Spanish]. Ecol. Arg. 5:1-16.

Lallana VH, 1981. [Productividad de Eichhornia crassipes (Pontederiaceae) en una laguna isleña de la cuenca del río Paraná Medio. I. Análisis del crecimiento].[Article in Spanish]. Bol. Soc. Argent. Bot. 20:99-107.

Lewandowski K, 1982. The role of early developmental stages in the dynamics of Dreissena polymorpha (Pall.) (Bivalvia) populations in lakes II. Settling of larvae and the dynamics of number of settled individuals. Ekol. Polska 30:223-286.

Manso MV, 2015. [Comportamiento trófico selectivo de Trichodactylus borellianus (Decapoda: Trichodactylidae) y su importancia como potencial depredador del bivalvo invasor Limnoperna fortunei (Bivalvia: Mytilidae) en ensayos de laboratorio].[Degree Thesis in Spanish]. Facultad de Humanidades y Ciencias, Universidad Nacional del Litoral, Argentina: $50 \mathrm{pp}$.

Marçal SF, Callil CT, 2008. Structure of invertebrates community associated with Eichhornia crassipes Mart. (SolmsLaubach) after the introduction of Limnoperna fortunei (Dunker, 1857) (Bivalvia, Mytilidae) in the Upper Paraguay River, MT, Brazil. Acta Limnol. Bras. 20:359-371.

Maroñas M, Darrigran G, Sendra E, Breckon G, 2003. Shell grow of the golden mussel, Limnoperna fortunei (Dunker, 1857) (Mytilidae), from a Neotropical temperate locality. Hydrobiologia 495:41-45.

Meerhoff M, Mazzeo N, 2004. [Importancia de las plantas flotantes libres de gran porte en la conservación y rehabilitación de lagos someros de Sudamérica].[Article in Spanish]. Ecosistemas 13:13-22.

Mesa L, Marchese MR, Montalto L, Zilli FL, 2012. Bidirectional exchanges of benthic invertebrates in a large riverfloodplain system (Paraná River, Argentina). Ann. Limnol. - Int. J. Lim. 48:425-436.

Michelan TS, Silveira MJ, Petsch DK, Pinha GD, Thomaz SM, 2014. The invasive aquatic macrophyte Hydrilla verticillata facilitates the establishment of the invasive mussel Limnoperna fortunei in Neotropical reservoirs. J. Limnol. 73:598-602.

Montalto L, Oliveros OB, Ezcurra de Drago I, Demonte LD, 1999. [Peces del río Paraná Medio predadores de una especie invasora: Limnoperna fortunei (Bivalvia, Mytilidae)].[Article in Spanish]. Rev. FABICIB 3:85-101.

Montalto L, Rojas Molina F. 2014. Periostracal adventitious hair in the Asian freshwater invasive bivalve Limnoperna fortunei (Mytilidae) in Paraná River system (South America). Molluscan Research 34:127-138.

Ohtaka A, Narita T, Kamiya T, Katakura H, Araki Y, Im S, Chhay R, Tsukawaki S, 2011. Composition of aquatic invertebrates associated with macrophytes in Lake Tonle Sap, Cambodia. Limnology 12:137-144.

Oliveira MD, Campos MCS, Paolucci E, Mansur MCD, Hamilton SK (2014). Colonization and spread of Limnoperna fortunei in South America, p. 333-355. In: D. Boltovskoy (ed.), Limnoperna fortunei: the ecology, distribution and control of a swiftly spreading invasive fouling mussel. Springer, Berlin (In press).

Oliveira MD, Hamilton SK, Calheiros DF, Jacobi CM, 2010. Oxygen depletion events control the invasive golden mussel 
(Limnoperna fortunei) in a Tropical Floodplain. Wetlands 30:705-716.

Oliveira MD, Takeda AM, Fernandes de Barros L, Sávio Barbosa D, de Resende EK, 2006. Invasion by Limnoperna fortunei (Dunker, 1857) (Bivalvia, Mytilidae) of the Pantanal wetland, Brazil. Biol. Invasions 8:97-104.

Paira AR, Drago EC, 2007. Origin, evolution, and types of floodplain water bodies, p. 53-81. In: M.H. Iriondo, J.C. Paggi and M.J. Parma (eds.), The Middle Paraná River: limnology of a subtropical wetland. Springer, Berlin.

Paoli C, Iriondo M, García N, 2000. [Características de las cuencas vecinas, p. 27-68]. In: C. Paoli and M. Schreider (eds.) [El río Paraná en su tramo medio. Contribución al conocimiento y prácticas ingenieriles en un gran río de llanura].[Book in Spanish]. Centro de Publicaciones, Secretaría de Extensión, UNL, Santa Fe, Argentina.

Paporello de Amsler G, 1987. [Fauna asociada a las raíces de Eichhornia crassipes en una laguna del valle aluvial del Río Paraná ("Los Matadores", Santa Fe, Argentina)].[Article in Spanish]. Rev. Asoc. Ciencias Nat. Litoral 18:93-103.

Poi de Neiff A, Carignan R, 1997. Macroinvertebrates in Eichhornia crassipes in two lakes of the Paraná River floodplain. Hydrobiologia 345:185-196.

Poi de Neiff A, Neiff JJ, 2006. [Riqueza de especies y similaridad de los invertebrados que viven en plantas flotantes de la planicie de inundación del Río Paraná (Argentina)].[Article in Spanish]. Interciencia 31:220-225.

R Development Core Team, 2008. R: A language and environment for statistical computing. R Foundation for Statistical Computing, Vienna, Austria.

Rohlf FJ, 2004. TPSDig2, version 1.40. Department of Ecology and Evolution, State University New York, Stony Brook.

Rojas Molina F, José de Paggi S, 2008. Zooplankton in the Paraná river floodplain (South America) before and after the invasion of Limnoperna fortunei (Bivalvia). Wetlands 28:695-702.

Rojas Molina F, José de Paggi S, Paggi JC, 2014. (in press). Impacts of Limnoperna fortunei on zooplankton, p. 177-190. In: D. Boltovskoy (ed.) Limnoperna fortunei: the ecology, distribution and control of a swiftly spreading invasive fouling mussel. Springer, Berlin.

Rojas Molina F, Paggi JC, Devercelli M, 2010. Zooplanktophagy in the natural diet and selectivity of the invasive mollusk Limnoperna fortunei. Biol. Invasions 12:1647-1659.

Rojas Molina F, Williner V, 2013. First record of the non-indigenous mussel Limnoperna fortunei (Bivalvia, Mytilidae) as an epibiont of the crab Trichodactylus borellianus (De- capoda, Trichodactylidae). Crustaceana 86:682-692.

Roland F, Esteves FA, Santos JE, 1990. [Decomposição da macrófita aquática Eichhornia azurea (Kunth), com ênfase na colonização por bactérias epifíticas].[Article in Portuguese]. Acta Limnol. Bras. 3:653-673.

Sabattini R, Lallana V, 2007. Aquatic macrophytes, p. 205-226. In: M.H. Iriondo, J.C. Paggi and M.J. Parma (eds.), The Middle Parana River: limnology of a subtropical wetland. Springer, Berlin.

Sala OE, Chapin FS, Armesto JJ, Berlow E, Bloomfield J, Dirzo R, Huber-Sanwald E, Huenneke LF, Jackson RB, Kinzig A, Leemans R, Lodge DM, Mooney HA, Oesterheld M, Poff NL, Sykes MT, Walker BH, Walker M, Wall DH, 2000. Global biodiversity scenarios for the year 2100 . Science 287:1770-1774.

Simberloff D, Martin JL, Genovesi P, Maris V, Wardle DA, Aronson J, Courchamp F, Galil B, García-Berthou E, Pascal M, Pysek P, Sousa R, Tabacchi E, Vilà M, 2013. Impacts of biological invasions: what's what and the way forward. Trends Ecol. Evol. 28:58-66.

Simberloff D, Von Holle B, 1999. Positive interactions of nonindigenous species: invasional meltdown? Biol. Invasions 1:21-32.

Spaccesi F, 2013. Abundance, recruitment, and shell growth of the exotic mussel Limnoperna fortunei in the Río de la Plata (Argentina). Zool. Stud. 52:1-11

Stripari N, Henry R. 2002. The invertebrate colonization during decomposition of Eichhornia azurea Kunth in a lateral lake in the mouth zone of Paranapanema River into Jurumirim Reservoir (São Paulo, Brazil). Braz. J. Biol. 62:293-310.

Sylvester F, Boltovskoy D, Cataldo DH, 2007. Fast response of freshwater consumers to a new trophic resourse: predation on the recently introduced Asian bivalve Limnoperna fortunei in the lower Paraná River, South America. Austral Ecol. 32:403-415.

Sylvester F, Dorado J, Boltovskoy D, Juarez A, Cataldo D, 2005. Filtration rates of the invasive pest bivalve Limnoperna fortunei as a function of size and temperature. Hydrobiologia 534:71-80.

Torres MV, Giri F, Williner V, 2012. Size selective predation on an invasive bivalve, Limnoperna fortunei (Mytilidae), by a freshwater crab, Zilchiopsis collastinensis (Trichodactylidae). J. Crustacean. Biol. 32(5):698-710.

Uryu Y, Iwasaki K, Hinoue M, 1996. Laboratory experiments on behavior and movement of a freshwater mussel, Limnoperna fortunei (Dunker). J. Mollus. Stud. 62:327-341. 